\title{
Re-thinking of blind pursuit of fanciful buildings in contemporary China
}

\author{
J.T. Weng ${ }^{1, a^{*}}$, Y.T. Ma ${ }^{1, b}$ \\ ${ }^{1}$ Room 506, Crescent Building, Zjingang Campus of Zhejiang University, Xihu District, Hangzhou City, \\ Zhejiang Province, China \\ a'815895960@qq.com, ${ }^{\mathrm{b}} 412617504 @ q q . c o m$
}

Keywords: Evaluation Standard; Fanciful Buildings; Common Buildings; Contemporary China

Abstract: Firstly the evolution of evaluation standard of architecture was reviewed, then the ten famous buildings built in National Day of 1959 in Beijing were introduced to compare with ten contemporary Chinese ugly buildings. A reflection on the dangers and root of the present fanciful buildings was made. Finally, we suggested that an effective bottom-up path should be established to encourage the expression of local regional and cultural consciousness appeals. Meanwhile, pay more attention to the common buildings and make the knowledge of architecture get involved in people's daily life.

\section{Introduction}

Since China's Reform and Opening up, the process of urbanization accelerated rapidly. China's urbanization rate was over $50 \%$ in 2011 . The scale of the city and the construction of the large amount expanded increasingly. In this process, our urban core and urban fringe have been great updated dramatically. Building form was paid close attention to by the society day by day. Take Beijing as an example, it appeared a group of outstanding original designs, meanwhile there were also some huge designs whose scale was out of control. Some visualization modeling were directly be applied in the architectural design. They greatly destroyed the original urban texture and city's image. Especially after CCTV new building was completed, the local government began to be flocking to the fanciful buildings, ignoring the basic architectural principles of strong, applicable, beautiful. This strange and unhealthy practices will seriously damage the overall image of the city. As the Dutch delft university of technology professor Alexander Para loch said," In the international design field there are two kinds of tends in recent years, the nonformalism advocating clutter and the formalism promoting power.[1]" This tendency directly resulted in the pursuit of fanciful buildings in China. So J.P. Xi, the president of China, said at a symposium on literature and art not long ago: "don't pursue fanciful buildings", which caused a heated discussion in architects.

The fast development of economics has brought more opportunities to architectural design. Great changes have taken place in people's way of thinking and aesthetic appeal[2]. With the improvement of the living standard in China, the requirement of construction quality and aesthetic is also increasing. Now fast-food type constructions based on a copy of form were produced by a large scale, with the increasing voice of pursuit of beauty and artistic quality[3]. The conflict between secularization and artistic contradictions has become increasingly prominent. On the one hand, China's ordinary people are lack of the basic cognition of architecture. People are more willing to debase architecture or regard it as esoteric knowledge. On the other hand, A remarkable gap of architecture education of elite route and extreme lack of voice in real society resulted in that architects keep silent in the link of promoting popular basic knowledge.

\section{The definition of fanciful buildings}

When we talk about the fanciful buildings, we can't avoid the definition of fanciful buildings. The evaluation standard of solidity, utility, beauty was proposed by the ancient Roman architect Vitruvius for the first time. This standard was used to give the fundamental evaluation. But this three elements are difficult to quantify. Importance is different in each cases. Later, function, technology, form, economic and environment were 
included in the architectural evaluation standard to assess the architectural design comprehensively. For example, the medieval churches and buildings emphasized combination of the aesthetic demands and building technology, structure, function. The evaluation standard began to focus on the embodiment of humanization. During the Renaissance, architectural form above all else, so building evaluation standard was lack of integrity. Based on the overall building evaluation standard, fanciful buildings are defined as follows, the buildings whose relationship between function and form is contradictory, or buildings which is contrary to the basic scientific principles, based on a copy of form and style or plain pursuit of grandness and luxury, blind faith in foreign things.

\section{0 famous buildings in 1959 and 10 contemporary Chinese ugly buildings}

\section{0 famous buildings built in Beijing in 1959.}

From the review of 10 famous buildings built in Beijing in 1959[4], such as the great hall of the people, Beijing railway station, the diaoyutai state guesthouse (figure 1) [5]. In the circumstance of limited input, this buildings accorded well with the principle of solidity, utility, beauty. This buildings inherited the Chinese typical architectural form successfully with the design technique of brief, capable and sprightly. So far except the overseas Chinese building was reconstructed in 1988, nine other buildings have experienced the test of more than 50 years and become excellent architectural and cultural relics.

\section{0 contemporary Chinese ugly buildings.}

Archcy.com combined severalexperts to launch "China top ten ugly building selection" for the first time in 2010[6], in order to criticize the pursuit of exoticism and fanaticism. Later media became one of the most significant participant in architectural criticism. CCTV new building, Beijing son of heaven hotel, Wuliangye wine bottle(figure 2), Huainan Olympic park, Hefei art gallery, Shanghai Minhang court, Shanghai face building, Shenyang square building, Chongqing jiangbei tiger mouth city building, Xianlesi square were listed. A classified evaluation was made based on criterias of ugly building. The result is shown in table 2 . The government behavior and commerce are the main driving force of the ugly buildings, the proportion were $40 \%$ and $60 \%$, respectively. $80 \%$ of the top ten were defined as strangely shaped. It meaned that people attached more importance to evaluation of actual appearance than other aspects.
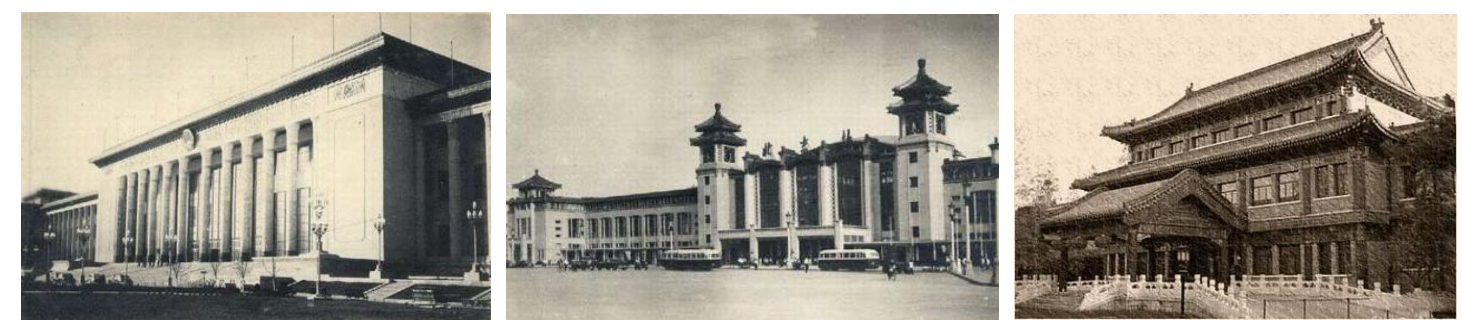

a. The great hall of the people $\mathrm{b}$. Beijing railway station $\mathrm{c}$. The guesthouse of diaoyutai state

Fig.1 Some old images of 10 famous buildings in 1959

Table.1 Summation of architectural form of 10 famous buildings in Beijing.

\begin{tabular}{l|l|l|l|l}
\hline $\begin{array}{l}\text { Architectural } \\
\text { style }\end{array}$ & The modernist & Socialist realism & $\begin{array}{l}\text { traditional form of Big } \\
\text { roof }\end{array}$ & New European classical \\
\hline Cases & $\begin{array}{l}\text { Ethnic restaurants, } \\
\text { The overseas chinese hotel, } \\
\text { Beijing workers' stadium }\end{array}$ & $\begin{array}{l}\text { The chinese people's war } \\
\text { museum }\end{array}$ & $\begin{array}{l}\text { Beijing railway station, } \\
\text { Agricultural exhibition } \\
\text { hall, Cultural palace, The } \\
\text { guesthouse of diaoyutai } \\
\text { state }\end{array}$ & $\begin{array}{l}\text { The great hall of the } \\
\text { people, The chinese } \\
\text { revolion and the } \\
\text { history museum }\end{array}$ \\
\hline
\end{tabular}



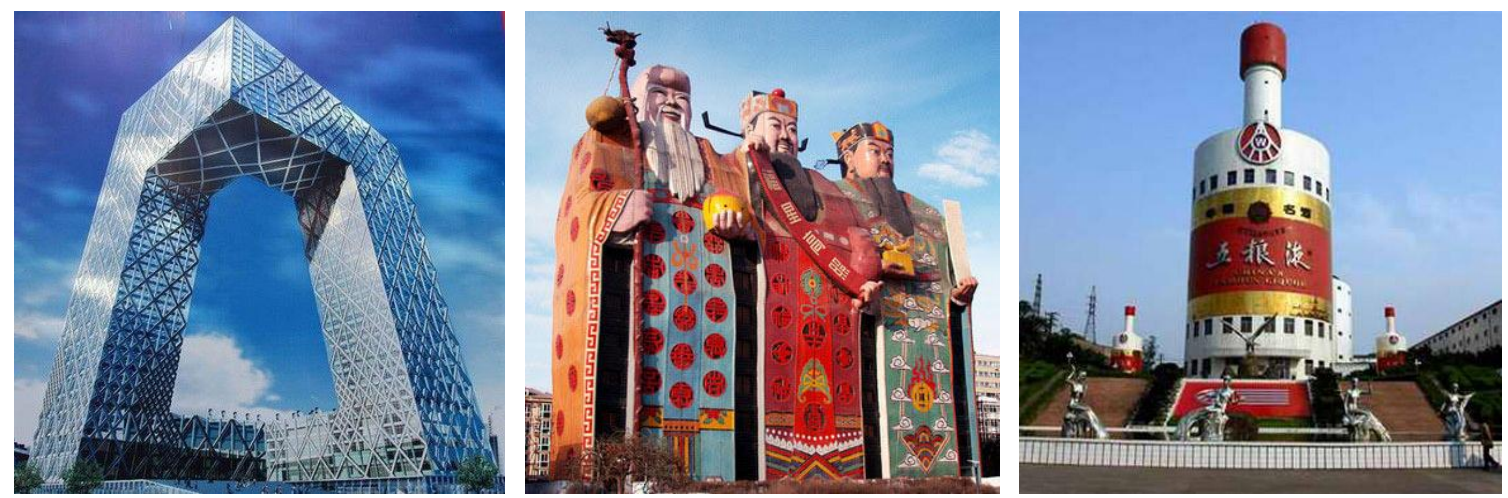

a. CCTV new building $\mathrm{b}$. Beijing son of heaven hotel c. Wuliangye wine bottle

Fig.2 Some images of 10 contemporary Chinese ugly buildings[6].

Table.2 Classified evaluation's result of 10 contemporary Chinese ugly buildings.

(gov- government, com-commerce, Y-yes, N-no, N/A-not available)

\begin{tabular}{|c|c|c|c|c|c|c|c|c|}
\hline & $\begin{array}{l}\text { Behavioral } \\
\text { agent }\end{array}$ & $\begin{array}{l}\text { Irrational } \\
\text { function }\end{array}$ & $\begin{array}{l}\text { Irrational } \\
\text { structure }\end{array}$ & $\begin{array}{l}\text { Metap } \\
\text {-horica } \\
1\end{array}$ & $\begin{array}{l}\text { Human- } \\
\text { environment } \\
\text { coordination }\end{array}$ & $\begin{array}{l}\text { Plagia- } \\
\text { rism }\end{array}$ & Worship & $\begin{array}{l}\text { Strangely } \\
\text { Shaped }\end{array}$ \\
\hline CCTV new building & gov & $\mathrm{Y}$ & $\mathrm{Y}$ & $\mathrm{N}$ & $\mathrm{Y}$ & $\mathrm{N}$ & $\mathrm{N}$ & $\mathrm{Y}$ \\
\hline $\begin{array}{l}\text { Beijing son of heaven } \\
\text { hotel }\end{array}$ & com & $\mathrm{Y}$ & $\mathrm{N}$ & $\mathrm{Y}$ & $\mathrm{Y}$ & $\mathrm{N}$ & N/A & $\mathrm{Y}$ \\
\hline Wuliangye wine bottle & com & $\mathrm{N}$ & $\mathrm{Y}$ & $\mathrm{Y}$ & $\mathrm{N}$ & $\mathrm{N}$ & $\mathrm{N}$ & $\mathrm{Y}$ \\
\hline Huainan Oly mpic park & gov & $\mathrm{N}$ & $\mathrm{N}$ & $\mathrm{Y}$ & $\mathrm{Y}$ & $\mathrm{N}$ & $\mathrm{N}$ & $\mathrm{Y}$ \\
\hline Hefei art gallery & gov & $\mathrm{Y}$ & $\mathrm{Y}$ & $\mathrm{Y}$ & $\mathrm{Y}$ & $\mathrm{Y}$ & $\mathrm{Y}$ & $\mathrm{Y}$ \\
\hline Shanghai Minhang court & gov & $\mathrm{N}$ & $\mathrm{N}$ & $\mathrm{N}$ & $\mathrm{N}$ & $\mathrm{Y}$ & $\mathrm{Y}$ & $\mathrm{N}$ \\
\hline Shanghai face building & com & $\mathrm{Y}$ & $\mathrm{N}$ & $\mathrm{N}$ & $\mathrm{N}$ & $\mathrm{N}$ & $\mathrm{N}$ & $\mathrm{N}$ \\
\hline $\begin{array}{l}\text { Sheny ang square } \\
\text { building }\end{array}$ & com & N/A & $\mathrm{N}$ & $\mathrm{Y}$ & $\mathrm{Y}$ & $\mathrm{Y}$ & $\mathrm{N}$ & $\mathrm{Y}$ \\
\hline $\begin{array}{l}\text { Chongqing jiangbei tiger } \\
\text { mouth city building }\end{array}$ & com & $\mathrm{Y}$ & $\mathrm{N}$ & $\mathrm{Y}$ & $\mathrm{Y}$ & $\mathrm{N}$ & $\mathrm{N}$ & $\mathrm{Y}$ \\
\hline Xianlesi square & com & $\mathrm{N}$ & $\mathrm{N}$ & $\mathrm{N}$ & $\mathrm{N}$ & $\mathrm{N}$ & $\mathrm{N}$ & $\mathrm{Y}$ \\
\hline
\end{tabular}

\section{The dangers and root of fanciful buildings}

\section{The dangers of fanciful buildings}

The blindness, unprincipled, unrestrained urban development mode will lead to irreparable consequences. German architecture critic Crufts pointed out that if the architectural theory was intervened by political ideology, in extreme case it would become the carrier of ideology. In a totalitarian societies, architectural theory existed as a kind of standard and unified style[7]. By referencing the thought of "The Society of the Spectacle ", G.C. Feng pointed out that fanciful buildings represented by the new CCTV building have been stripped out from the architecture by political power, they are losing its advanced position and the nature of pioneer in the field of construction. Fanciful buildings only account for a small proportion and seem a bit detached from daily life. But they attract almost all of the attention and voice in the field of construction, which causes that common buildings in our daily life have been forgotten by people.

\section{The root of fanciful buildings}

Depending on the implementing subject, the main strange buildings are divided into two kinds, one is the so-called prestige projects launched by the government. From the Beijing Olympic Games to the Guangzhou Asian games, the progress of urban renovation never stops. Another one is the gimmick created by developer. The external form and internal function of the buildings are separated. The form of the building is freely 
fabricated to meet the needs of the business marketing. So every few years there will be some new architectural style, such as revitalized style, European classical style and so on.

Firstly, the architects and architectural critics is lack of voice. Secondly, The leaders of government department show more attention on externals. The layman's subjective intervention will often contribute to a fanciful buildings. Thirdly. Limited by time ,manpower, and resources, quality of architectural design is not high enough. At last, a low level of public participation and low degree of transparency in domestic architectural design results in that the oversight system of scheme selection is not sound enough.

\section{Conclusion}

S.C. Liang said, "Architecture won't get the highest developed, until the society begins to emphasize on architecture and architects. Only when the ordinary people begin to understand the basic cognition of architecture, the real construction comes and architect have the chance to use their creative skills." These points are still relevant today in China. According to present situation of urban construction in China, two solutions to solve the problem of fanciful buildings are put forward:

1.Establish an effective bottom-up path to encourage the expression of local regional and cultural consciousness appeals. Achieve a harmonious relationship with the environment and show the local characteristic. Architecture design not only need to meet the requirements of professional principles, but also should consider the aesthetic of the public. Correct pursuit of the fanciful building through institutional constraints and public scrutiny.

2.Pay more attention to the common buildings and make knowledge of architecture get involved in people's daily life. The value of silence and common buildings should be claimed by the society. It's time to promote the quality of common buildings. Excellent building works not only need to pay attention to dimensional function, construction technology, building materials and construction methods, but also need to emphasize the embodiment of humanization. The architecture should be merged with psychology, sociology and computer science to make the connotation of architecture be various.

\section{Acknowledgments}

This research was supported by Project in the National Science \& Technology Pillar Program during the Twelfth Five-year Plan Period (Project name: Evaluation and optimization of building energy consumption system \& Research and demonstration of self-insulation system, Project number: 2011BAJ03B11)

\section{References}

[1] L.Y. Wu, UIA Beijing Charter-the future of architecture, Beijing, Tsinghua University Press,2002,29-30.

[2] Y.F. Li, since the Reform and Opening up studies on the trend of Chinese architectural aesthetics, Tianjin University, 14-15.

[3] J.G. Wang, revolution of Chinese architectural design at the new-type urbanization stage, Frontiers of Architectural Research.4(2015)248-250.

[4] Y.K. Yang, 10 famous buildings built in Beijing in 1950s, Beijing Archives, 4-8.

[5] Information on http://www.chinese.cn/zhuanti/2009/article/2009-09/16/content_65258.htm

[6] Information on http://www.archcy.com/votes/2010

[7] H.W. Kruft, a history of architecture theory: from Vitruvius to the present, 1985,282-311. 